\title{
Stream fish from recently deforested basins in the Meridional Amazon, Mato Grosso, Brazil
}

\author{
Lilian Casatti $^{1 *}{ }^{\oplus}$, Gabriel Lourenço Brejão $o^{1}{ }^{\circledR}$, Fernando Rogério Carvalho $^{2}{ }^{\circledR}$, Hugmar Pains da Silva ${ }^{\circledR}$, \\ María Angélica Pérez-Mayorga ${ }^{1}{ }^{\circledR}$, Angelo Rodrigo Manzotti ${ }^{1}{ }^{\circledR}$, Jaquelini de Oliveira Zeni ${ }^{\circledR}$, Bruno Martins \\ Santos Ramires ${ }^{1}$ \& Francisco Langeani $^{1(1)}$ \\ 'Universidade Estadual Paulista "Júlio de Mesquita Filho", Departamento de Zoologia e Botânica, \\ Laboratório de Ictiologia, Rua Cristóvão Colombo, 2265, CEP 15054-000, São José do Rio Preto, SP, Brasil \\ ${ }^{2}$ Universidade Federal de Mato Grosso do Sul, Instituto de Biociências, Laboratório de Ictiologia, Avenida \\ Costa e Silva, s/n, Cidade Universitária, CEP 79070-900, Campo Grande, MS, Brasil \\ ${ }^{3}$ Universidade Federal de Mato Grosso, Laboratório de Citogenética e Genética Animal, Instituto de \\ Biociências, Avenida Fernando Correa da Costa, 2367, CEP 78060-900, Cuiabá, MT, Brasil \\ ${ }^{4}$ Universidade Estadual Paulista "Júlio de Mesquita Filho”, Departamento de Ecologia, Av. 24-A, 1515, \\ CEP: 13506-900, Rio Claro, SP, Brasil \\ *Corresponding author: Lilian Casatti,e-mail: licasatti@gmail.com
}

CASATTI, L., BREJÃO, G.L., CARVALHO, F.R., SILVA, H.P., PÉREZ-MAYORGA, M.A., MANZOTTI, A.R., ZENI, J.O. RAMIRES, B.M.S, LANGEANI, F. Stream fish from recently deforested basins in the Meridional Amazon, Mato Grosso, Brazil. Biota Neotropica. 20(1): e 20190744. http://dx.doi.org/10.1590/1676-0611BN-2019-0744

\begin{abstract}
The replacement of tropical forests to production systems is one of the leading causes of riverine ecosystem alterations. However, current assemblages' composition may also result from the time since these transformations have begun. Therefore, the knowledge of diversified historical scenarios can facilitate the accomplishment of actions that involve the aquatic environments recovery. In this study, an inventory of stream fish was carried out in basins whose deforestation was intensified in the last 20 years, to compose a baseline for ecological and taxonomic studies. The habitat, physical and chemical variables, and the fish assemblages from 60 streams in the northwest region of the state of Mato Grosso, in the Aripuanã and Juruena river basins, were sampled with standardized procedures. For a total of 130 species, a numerical predominance of small-sized Characidae and great rarity were registered, with 50 species represented by less than ten individuals and 19 singletons. Approximately $15 \%$ of the sampled taxa were identified only at the generic level, and for several taxa, more detailed taxonomic and molecular studies are required in order to achieve satisfactory identifications. None threatened species were so far reported. On the other hand, two specimens of non-native species were sampled. Although habitat quality is higher in forested streams, no differences in the species richness were registered when compared to the pasture with riparian forest streams or to more deforested streams. However, abundance was greater in these last two streams groups as a result of small-sized characins dominance.
\end{abstract}

Keywords: inventory, neotropical ichthyofauna, deforestation, baseline, Characidae.

\section{Peixes de riachos de bacias recentemente desmatadas na Amazônia Meridional, Mato Grosso, Brasil}

Resumo: A substituição de florestas tropicais por sistemas de produção representa uma das principais fontes de alteração nos ecossistemas de riachos. Contudo, a composição atual das assembleias também depende do tempo decorrente desde o início dessas transformações e, desta forma, o conhecimento de cenários históricos variados pode facilitar a realização de ações que envolvam a recuperação de ambientes aquáticos. Neste estudo, foi realizado o inventário dos peixes de riachos em bacias cujo desmatamento foi intensificado nos últimos 20 anos, para compor uma linha de base que possa ser usada em estudos ecológicos e taxonômicos. Foram amostradas as variáveis do hábitat, físicas e químicas e os peixes de 60 riachos da região noroeste do estado de Mato Grosso, nas bacias dos rios Aripuanã e Juruena. No total, 130 espécies foram registradas, com predominância numérica de pequenos caracídeos e grande número de espécies raras, sendo 50 espécies representadas por menos que dez indivíduos e 
19 por apenas um indivíduo. Aproximadamente $15 \%$ dos táxons amostrados foram identificados somente no nível genérico e vários precisam de estudos taxonômicos e moleculares mais detalhados para alcançar identificações satisfatórias. As espécies não-nativas foram representadas por dois exemplares e nenhuma espécie sabidamente ameaçada foi registrada. Embora a qualidade do hábitat seja superior nos riachos florestados, não houve diferenças na riqueza das assembleias quando comparada aos riachos de microbacias de pastagem, porém com faixa ripária florestada, ou com maior desmatamento. Contudo, a abundância foi maior nesses dois grupos de riachos, como resultado da dominância de caracídeos de pequeno porte.

Palavras-chave: inventário, ictiofauna neotropical, desmatamento, linha de base, Characidae.

\section{Introduction}

The land use in the watershed can alter environmental characteristics that influence the populations' performance (Jonsson et al. 2011) and the fish assemblages' composition (Roth et al. 1996, Stauffer et al. 2000). Nearby to the water bodies, the riparian buffer integrity shows great influence on the aquatic environment and its components (see Pusey \& Arthington 2003, Quinn 2005, Teels et al. 2006, Lorion \& Kennedy 2009, Luke et al. 2019 and authors therein). Although several studies explore watershed and riparian scales, little is known about how the history of land use changes affects current communities and ecosystems (but see Maloney \& Weller 2011, Aguirre-Gutierrez et al. 2015, Östlund et al. 2015). Harding et al. (1998) were the first ones to highlight the importance of land use history on the current fish fauna composition in North American streams. Indeed, historical data may show that two distinct areas can present similar land coverage, but with different trajectories through time (Ferraz et al. 2009); that is, deforestation may have occurred at the beginning of human occupation or later, or have been abrupt or gradual. These differences may explain to a great extent the composition and diversity patterns of current assemblages (Maloney \& Weller 2011, Brejão et al. 2018).

One way to investigate community modifications over time is by obtaining baselines in areas that were modified at different times along history. Recently, the Southern Amazon, in the state of Mato Grosso, has been a target of an intense deforestation (Valdiones et al. 2018). Despite this, in this region there are a significant number of protected areas as indigenous lands, sustainable use units, and legal reserves. This landscape configuration represents a very diversified environmental gradient, allowing us to understand how deforestation under different historical land use changes affects fish fauna. Thus, our aim was to carry out an inventory of stream fish assemblages in watersheds whose deforestation has been intensified for the last 20 years to compose a baseline that can be used in future ecological and taxonomic studies, as well as to subsidize basin management and restoration actions.

\section{Materials and Methods}

\section{Study area and site selection}

The study area was located in the northwest portion of the Mato Grosso State, in the Cotriguaçu, Juína, and Aripuanã municipalities (Figure 1, Table 1). The Mato Grosso State has an area of $903,357 \mathrm{~km}^{2}$ and it is the third largest state of Brazil, including portions of the Amazon, Cerrado, and Pantanal biomes (Picoli et al. 2018). The Amazonian biome in Mato Grosso includes the Amazon Forest and the Seasonal Forest, which together occupy about $53 \%$ of the territory of the state (Picoli et al. 2018). This study was developed in areas of Amazon Forest, in the middle portion of the Aripuanã and Juruena (left bank) rivers, which are included in the Madeira Brazilian Shield and Tapajós-Juruena ecoregions (Abell et al. 2008, WWF \& TNC 2015). These drainages were chosen due to the recent deforestation, with higher intensity occurring after 2000 (Figure 1) and because the primary land use conversion was from forest to pasture (Figure 2).

Using Geographic Information Systems (GIS) tools, 30 independent watersheds were selected in each river basin, which resulted in 60 stream reaches to be sampled. Samples were carried out at the beginning of the dry season (between May and July) in 2017 and 2018 to avoid possible changes related to seasonality. Stream reaches were from first to third order (according to Strahler 1957) and $80 \mathrm{~m}$ long. Three scenarios were sampled (Figure 3, Table 1): 16 streams with more than $50 \%$ native forests covering the watershed and the riparian buffer (FOR); 15 streams with pasture predominance in the watershed, but with more than $50 \%$ the riparian buffer covered by forests (PAS+RIP); and 29 streams with less than $50 \%$ of forests in the watershed and in the riparian buffer (DEF).

\section{Data collection}

Before the fish sampling, the stream habitat was quantified with a standardized protocol that evaluates the physical structure in the instream and riparian area, by calculating the Physical Habitat Index (PHI) based on Barbour et al. (1999), Kazyak (2001) and modified by Casatti et al. (2006). PHI varies from 0 to 180 : from 0 to 45 , conditions indicate strong deviation from the minimally disturbed references; from 46 to 90 , there is significant deviation from the references; from 91 to 135 , conditions indicate that some aspects of physical habitat may not resemble those found in references; from 136 to 180 , streams are comparable to minimally disturbed references (Roth et al. 1996).

Fish sampling was conducted under ICMBio ("Instituto Chico Mendes de Conservação da Biodiversidade”) permits (8894-1/2017, 11435-1/2018). Upstream and downstream reaches were blocked using block nets ( $5 \mathrm{~mm}$ mesh) and, during one hour, two collectors sampled fish with a seine $(1.5 \times 2 \mathrm{~m}, 2 \mathrm{~mm}$ mesh $)$ and a dip net $(0.5 \times 0.8 \mathrm{~m}, 2$ $\mathrm{mm}$ mesh). Soon after the collection, fishes were euthanized in clove oil solution (Lucena et al. 2013). Fish identification was conducted by specialists, and all specimens are deposited in the Fish Collection of the Zoology and Botany Department (DZSJRP, vouchers 21469-22629), in the São Paulo State University "Júlio de Mesquita Filho", São José do Rio Preto, São Paulo State, Brazil.

\section{Data analysis}

The inventory representativeness was evaluated by the Coleman rarefaction (Colwell et al. 2004), which was compared to other two nonparametric richness estimators, the ICE (Incidence Coverage Estimator, 

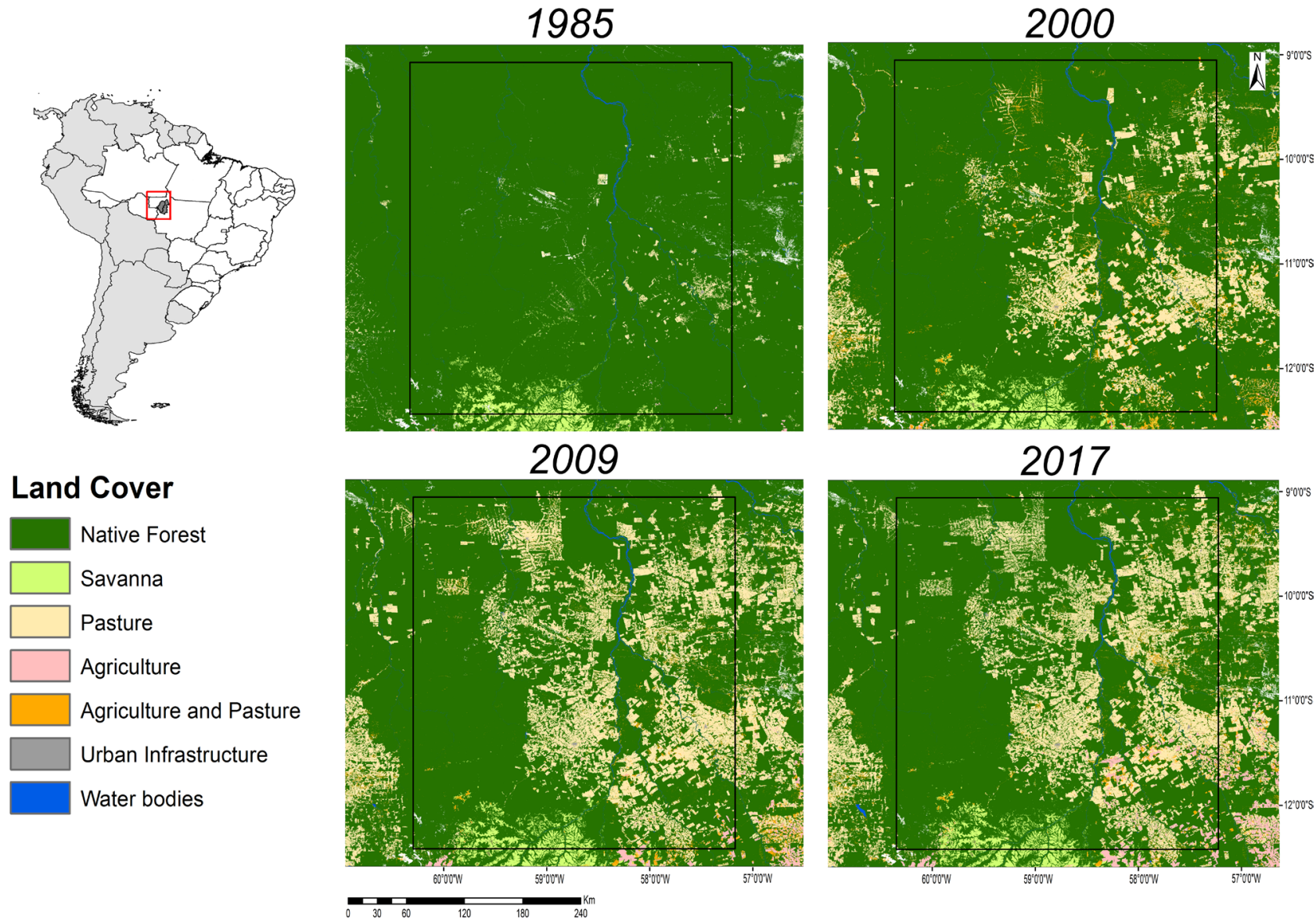

Figure 1. Land cover in the northwest Mato Grosso State from 1985 to 2017 (MAPBIOMAS, 2019). The red square in the country map indicates the studied region.

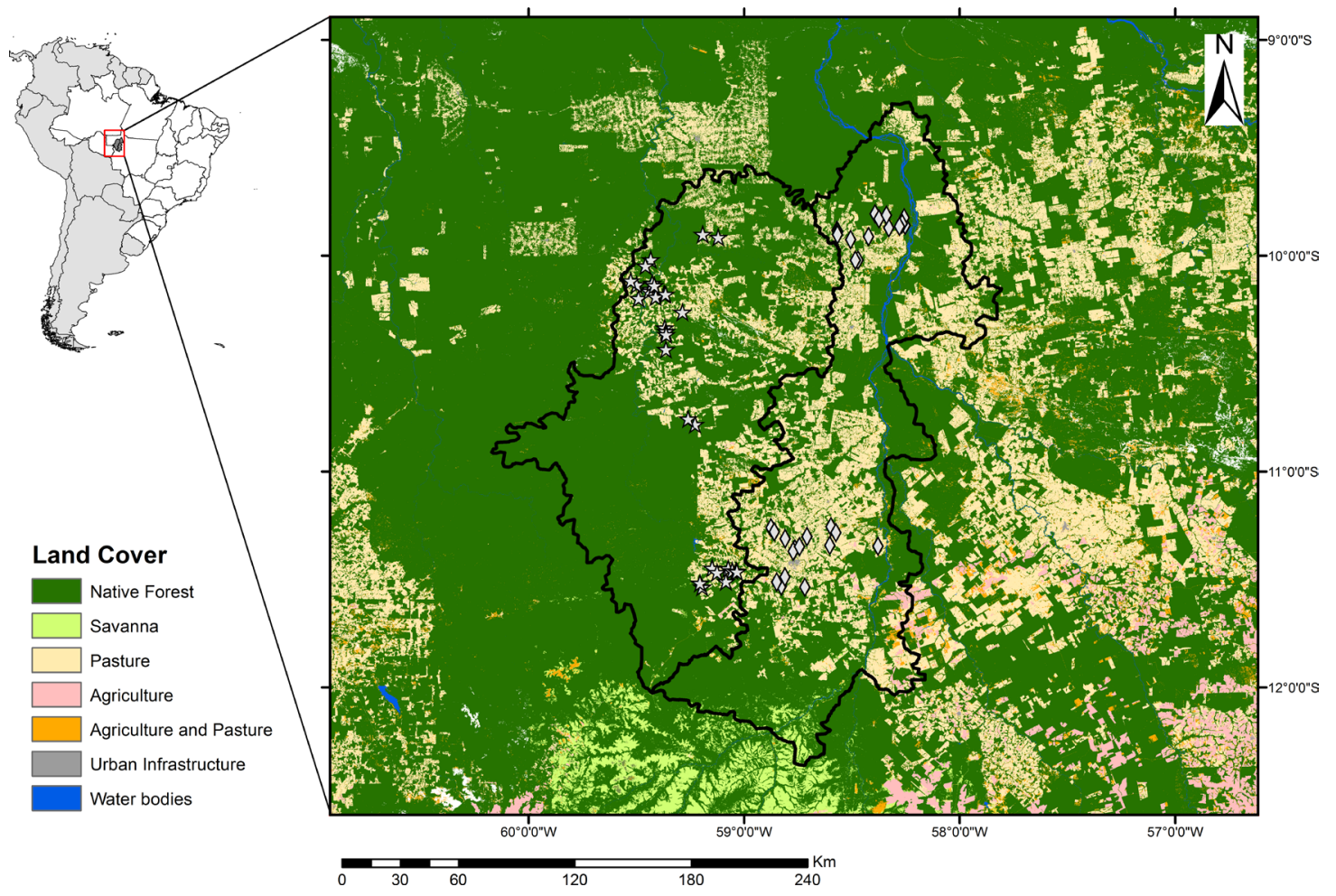

Figure 2. Location of the Aripuanã (stars) and Juruena (diamonds) sampled reaches in the Mato Grosso State, Brazil. The red square in the country map indicates the studied region. Land cover was based on MAPBIOMAS (2019). 
Table 1. Geographical coordinates (X, Y, UTM zone 21L, datum WGS84) and municipalities of the 60 streams sampled in the Aripuanã (A) and Juruena (J) river basins, Mato Grosso State, Brazil, according to their groups (FOR, forested; PAS+RIP, pasture with riparian forests, DEF, deforested).

\begin{tabular}{|c|c|c|c|c|c|c|c|c|c|}
\hline ID & $\mathbf{X}$ & $\mathbf{Y}$ & Municipalities & Groups & ID & $\mathbf{X}$ & $\mathbf{Y}$ & Municipalities & Groups \\
\hline A7 & 233378 & 8891583 & Aripuanã & FOR & J29 & 0338827 & 8892060 & Cotriguaçu & PAS+RIP \\
\hline A8 & 230757 & 8888490 & Aripuanã & FOR & A2 & 233183 & 8876438 & Aripuanã & DEF \\
\hline A9 & 259716 & 8904825 & Aripuanã & FOR & A4 & 240342 & 8873978 & Aripuanã & DEF \\
\hline A10 & 267681 & 8903390 & Aripuanã & FOR & A6 & 236024 & 8872545 & Aripuanã & DEF \\
\hline A13 & 226347 & 8878700 & Aripuanã & FOR & A16 & 240805 & 8856783 & Aripuanã & DEF \\
\hline A17 & 241349 & 8854972 & Aripuanã & FOR & A18 & 241512 & 8853320 & Aripuanã & DEF \\
\hline A19 & 241488 & 8845724 & Aripuanã & FOR & A22 & 273929 & 8733554 & Juína & DEF \\
\hline A 20 & 256488 & 8807420 & Aripuanã & FOR & A23 & 275946 & 8732520 & Juína & DEF \\
\hline A21 & 253042 & 8810164 & Aripuanã & FOR & A24 & 277753 & 8732329 & Juína & DEF \\
\hline A26 & 272791 & 8726933 & Juína & FOR & A27 & 265777 & 8733720 & Juína & DEF \\
\hline A28 & 260704 & 8723926 & Juína & FOR & $\mathrm{J} 1$ & 0300866 & 8724744 & Juína & DEF \\
\hline $\mathrm{J} 18$ & 0362236 & 8913869 & Cotriguaçu & FOR & $\mathrm{J} 2$ & 0298447 & 8726758 & Juína & DEF \\
\hline $\mathrm{J} 21$ & 0361200 & 8910845 & Cotriguaçu & FOR & $\mathrm{J} 3$ & 0302592 & 8729477 & Juína & DEF \\
\hline $\mathrm{J} 22$ & 0359823 & 8909364 & Cotriguaçu & FOR & $\mathrm{J} 5$ & 0307532 & 8743830 & Juína & DEF \\
\hline $\mathrm{J} 26$ & 0347332 & 8915782 & Cotriguaçu & FOR & J6 & 0306712 & 8742555 & Juína & DEF \\
\hline J27 & 0349420 & 8913214 & Cotriguaçu & FOR & $\mathrm{J} 7$ & 0313600 & 8750169 & Juína & DEF \\
\hline $\mathrm{A} 1$ & 227350 & 8871821 & Aripuanã & PAS+RIP & $\mathrm{J} 8$ & 0325761 & 8755312 & Juína & DEF \\
\hline $\mathrm{A} 3$ & 232603 & 8875583 & Aripuanã & PAS+RIP & J9 & 0328313 & 8752288 & Juína & DEF \\
\hline A5 & 234184 & 8879533 & Aripuanã & PAS+RIP & $\mathrm{J} 10$ & 0325269 & 8745762 & Juína & DEF \\
\hline A11 & 235275 & 8878407 & Aripuanã & PAS+RIP & J11 & 0349605 & 8745429 & Juína & DEF \\
\hline A12 & 241074 & 8874028 & Aripuanã & PAS+RIP & $\mathrm{J} 12$ & 0295350 & 8754632 & Juína & DEF \\
\hline A14 & 223304 & 8880776 & Aripuanã & PAS+RIP & $\mathrm{J} 13$ & 0297087 & 8752553 & Juína & DEF \\
\hline A15 & 249723 & 8864879 & Aripuanã & PAS+RIP & J14 & 0302552 & 8749054 & Juína & DEF \\
\hline A25 & 278336 & 8731978 & Juína & PAS+RIP & $\mathrm{J} 15$ & 0309902 & 8745005 & Juína & DEF \\
\hline A29 & 259643 & 8725961 & Juína & PAS+RIP & $\mathrm{J} 16$ & 0362678 & 8909927 & Cotriguaçu & DEF \\
\hline A30 & 268210 & 8731484 & Juína & PAS+RIP & $\mathrm{J} 17$ & 0354388 & 8908701 & Cotriguaçu & DEF \\
\hline $\mathrm{J} 4$ & 0312725 & 8724285 & Juína & PAS+RIP & $\mathrm{J} 20$ & 0344172 & 8904108 & Cotriguaçu & DEF \\
\hline J19 & 0335065 & 8902505 & Cotriguaçu & PAS+RIP & $\mathrm{J} 23$ & 0328127 & 8907223 & Cotriguaçu & DEF \\
\hline $\mathrm{J} 25$ & 0328326 & 8905007 & Cotriguaçu & PAS+RIP & $\mathrm{J} 24$ & 0328417 & 8906436 & Cotriguaçu & DEF \\
\hline $\mathrm{J} 28$ & 0353157 & 8915101 & Cotriguaçu & PAS+RIP & $\mathrm{J} 30$ & 0337440 & 8891940 & Cotriguaçu & DEF \\
\hline
\end{tabular}

Lee \& Chao 1994) and the ACE (Abundance Coverage Estimator, Lee \& Chao 1994), using the software EstimateS 9.10 (Colwell 2013). Species with only one specimen were considered singletons and those that occurred only in one stream reach were considered as uniques (Colwell 2013). The Kruskal-Wallis test was used to compare PHI, species richness, and abundance between stream groups (significance level $\alpha=0.05$ ), since the normal distribution was rejected according to the previously Shapiro-Wilk test applied to these variables. The Dunn's post hoc test was carried out after obtaining a significant result in a Kruskal-Wallis test. These analyses were conducted in the PAST 3.25 software (Hammer et al. 2001). Whittaker plots (relative abundance in the $\mathrm{y}$-axis and abundance rank in the $\mathrm{x}$-axis) were constructed to describe the species abundance patterns in each stream group (Matthews \& Whittaker 2015).

\section{Results}

A total of 18,504 specimens belonging to 130 species, 73 genera, 27 families, and six orders were collected (Table 2). Seven species of small characins (Knodus sp. 1, Hemigrammus cf. rodwayi, Jupiaba acanthogaster, Moenkhausia levidorsa, Inpaichthys kerri, Moenkhausia oligolepis, and Hyphessobrycon aff. agulha) accounted for more than $50 \%$ of the total abundance in the streams from Aripuanã and Juruena river basins (Table 2, Figure 4). On the other hand, 50 species were represented by less than ten individuals and 19 were singletons. Regarding occurrence, eight species were present in at least $50 \%$ of the sites (Knodus sp. 1, Characidium aff. zebra, Moenkhausia oligolepis, Rineloricaria sp., Ituglanis cf. amazonicus, Aequidens gerciliae, Hoplias cf. malabaricus, and Eigenmannia macrops, Figure 4) whereas 39 species were uniques (Table 2). Two specimens of the non-native 

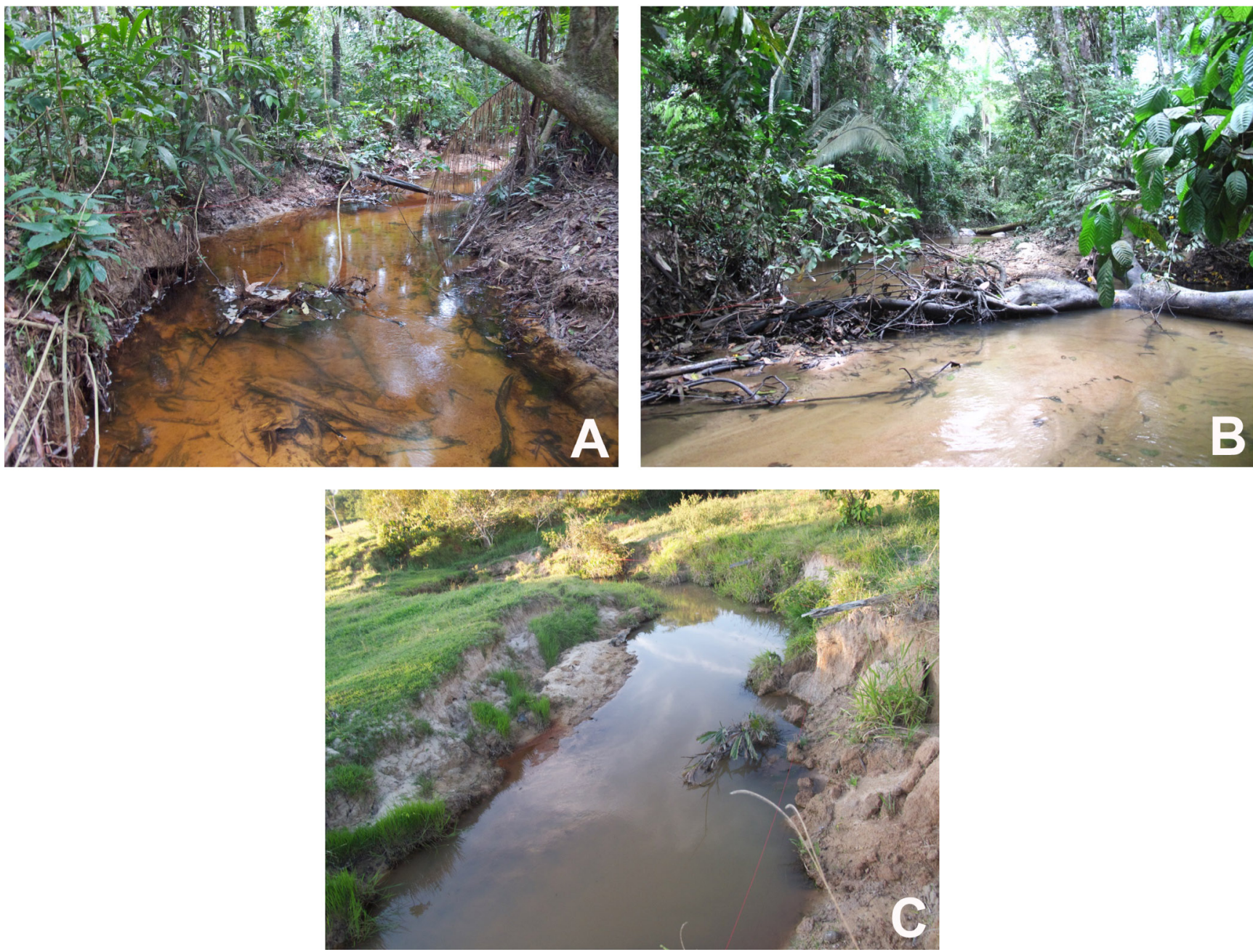

Figure 3. General view of a forested stream (A), a stream in a pasture microbasin, but with forested riparian buffer (B), and a deforested stream (C). In order, streams are J18, J19, and J15. Photos: María Angélica Pérez-Mayorga.

Oreochromis niloticus and no endangered or threatened species were recorded. ACE and ICE indicated that the set of species in this area could reach 147 and 171 species, respectively (Figure 5).

Forested streams showed the highest physical habitat quality (Chi-square $=14.14, P=0.0008$, Figure 6 ). Although the differences in terms of the physical habitat quality, species richness did not differ significantly among groups (Chi-square $=4.31, P=0.1145$, Figure 7A). However, species abundance was significantly lower in forested streams when compared to the others (Chi-square $=15.76, P=0.0004$, Figure 7B, Figure 8).

\section{Discussion}

In terms of orders or families' composition, the present inventory is in agreement with several studies conducted in the Neotropical streams since Lowe-McConnell (1999), where Characiformes and Siluriformes species represent the classical fish composition (cf. also Reis et al. 2003, Barros et al. 2011, Buckup et al. 2011, Queiroz et al. 2013, Ohara et al. 2017). Indeed, any deviation from Characiformes and Siluriformes prevalence can be expected in degraded conditions, where non-native opportunist species of the Cichliformes and Cyprinodontiformes may prevail (Ferreira et al. 2018, Ruaro et al. 2018). Since Aripuanã and Juruena river basins are under relatively recent occupation, this is not the case until now. Whereas the major families and orders are well known, the same is not true at the species level. Almost $15 \%$ of the sampled taxa were identified only to genus level, and several of them require more detailed taxonomic and molecular studies (e.g., Astyanax aff. bimaculatus, Characidium aff. zebra, Rhamdia aff. quelen). Ancistrus and Hypostomus members deserve special attention because of their great diversity inter and intrabasins, probably with undescribed species. Hemiodus bimaculatus was recently described by Nogueira et al. (2019) and two other putative new species of Astyanax and Hyphessobrycon are being analyzed by our team (Carvalho et al. 2019).

One of the first studies in this region was developed by Soares (1979), in one stream from the Aripuanã river basin. Of 20 fish species recorded by her, seven were unidentified at species level. This clearly demonstrates that, even 40 years later, the taxonomic resolution of Amazonian fishes still demands for more detailed studies and the overall fish diversity of this biome is far from being properly known. 
Table 2. Overall abundance and frequency of occurrence (FO, in \%) of each fish species sampled in the stream reaches of the Aripuanã (A) and Juruena (J) river basins. Relative abundance (in \%) of each species is presented according to the stream condition (FOR, forested; PAS+RIP, pasture with riparian forests, DEF, deforested). Classification follows Frick et al. (2019). Asterisk indicate non-native species.

\begin{tabular}{|c|c|c|c|c|c|c|}
\hline TAXON & $\mathbf{A}$ & $\mathbf{J}$ & FO & FOR & PAS+RIP & DEF \\
\hline \multicolumn{7}{|l|}{ CHARACIFORMES } \\
\hline \multicolumn{7}{|l|}{ Parodontidae } \\
\hline \multicolumn{7}{|l|}{ Curimatidae } \\
\hline Cyphocharax gangamon Vari, 1992 & 0 & 49 & 20 & 0.66 & 0.25 & 0.19 \\
\hline Steindachnerina fasciata (Vari \& Géry, 1985) & 8 & 6 & 15 & & & \\
\hline \multicolumn{7}{|l|}{ Prochilodontidae } \\
\hline Prochilodus nigricans Spix \& Agassiz, 1829 & 27 & 1 & 8 & 0.04 & 0.47 & 0.01 \\
\hline \multicolumn{7}{|l|}{ Anostomidae } \\
\hline Leporinus gomesi Garavello \& Santos, 1981 & 25 & 0 & 13 & 0.31 & 0.13 & 0.10 \\
\hline Leporinus reticulatus Britski \& Garavello, 1993 & 0 & 4 & 2 & 0 & 0.07 & 0 \\
\hline Leporinus cf. santosi Britski \& Birindelli, 2013 & 0 & 48 & 15 & 0 & 0.24 & 0.33 \\
\hline \multicolumn{7}{|l|}{ Crenuchidae } \\
\hline Elachocharax pulcher Myers, 1927 & 0 & 12 & 2 & 0 & 0.22 & 0 \\
\hline Characidium aff. zebra Eigenmann, 1909 & 122 & 180 & 77 & 0.79 & 2.16 & 1.54 \\
\hline Characidium sp. & 0 & 2 & 2 & 0 & 0.04 & 0 \\
\hline Melanocharacidium cf. auroradiatum Costa \& Vicente, 1994 & 0 & 8 & 2 & 0 & 0.15 & 0 \\
\hline \multicolumn{7}{|l|}{ Hemiodontidae } \\
\hline Bryconops cf. caudomaculatus (Günther, 1864) & 260 & 23 & 48 & 2.85 & 2.30 & 0.85 \\
\hline Bryconops cf. giacopinii (Fernández-Yépez, 1950) & 0 & 40 & 15 & 0.26 & 0.02 & 0.31 \\
\hline \multicolumn{7}{|l|}{ Characidae } \\
\hline Aphyocharax sp. & 1 & 0 & 2 & 0 & 0.02 & 0 \\
\hline Astyanax cf. anterior Eigenmann, 1908 & 256 & 0 & 12 & 2.81 & 1.65 & 0.94 \\
\hline Astyanax aff. bimaculatus (Linnaeus, 1758) & 17 & 44 & 23 & 0.09 & 0.22 & 0.44 \\
\hline Astyanax cf. maximus (Steindachner, 1876) & 215 & 22 & 32 & 2.90 & 0.67 & 1.25 \\
\hline Astyanax sp. & 81 & 49 & 33 & 1.27 & 0.33 & 0.77 \\
\hline Creagrutus ignotus Vari \& Harold, 2001 & 0 & 228 & 28 & 0.09 & 1.36 & 1.41 \\
\hline Creagrutus petilus Vari \& Harold, 2001 & 30 & 0 & 3 & 0 & 0.54 & 0 \\
\hline Hemigrammus cf. geisleri Zarske \& Géry, 2007 & 1 & 0 & 2 & 0 & 0.02 & 0 \\
\hline Hemigrammus cf. lunatus Durbin, 1918 & 87 & 0 & 2 & 0 & 1.58 & 0 \\
\hline Hemigrammus microstomus Durbin, 1918 & 0 & 1 & 2 & & & \\
\hline Hemigrammus aff. ocellifer (Steindachner, 1882) & 0 & 1 & 2 & 0.04 & 0 & 0 \\
\hline Hemigrammus cf. parana Marinho, Carvalho, Langeani \& Tatsumi, 2008 & 0 & 31 & 5 & 0.70 & 0 & 0.14 \\
\hline
\end{tabular}


Continuation Table 2.

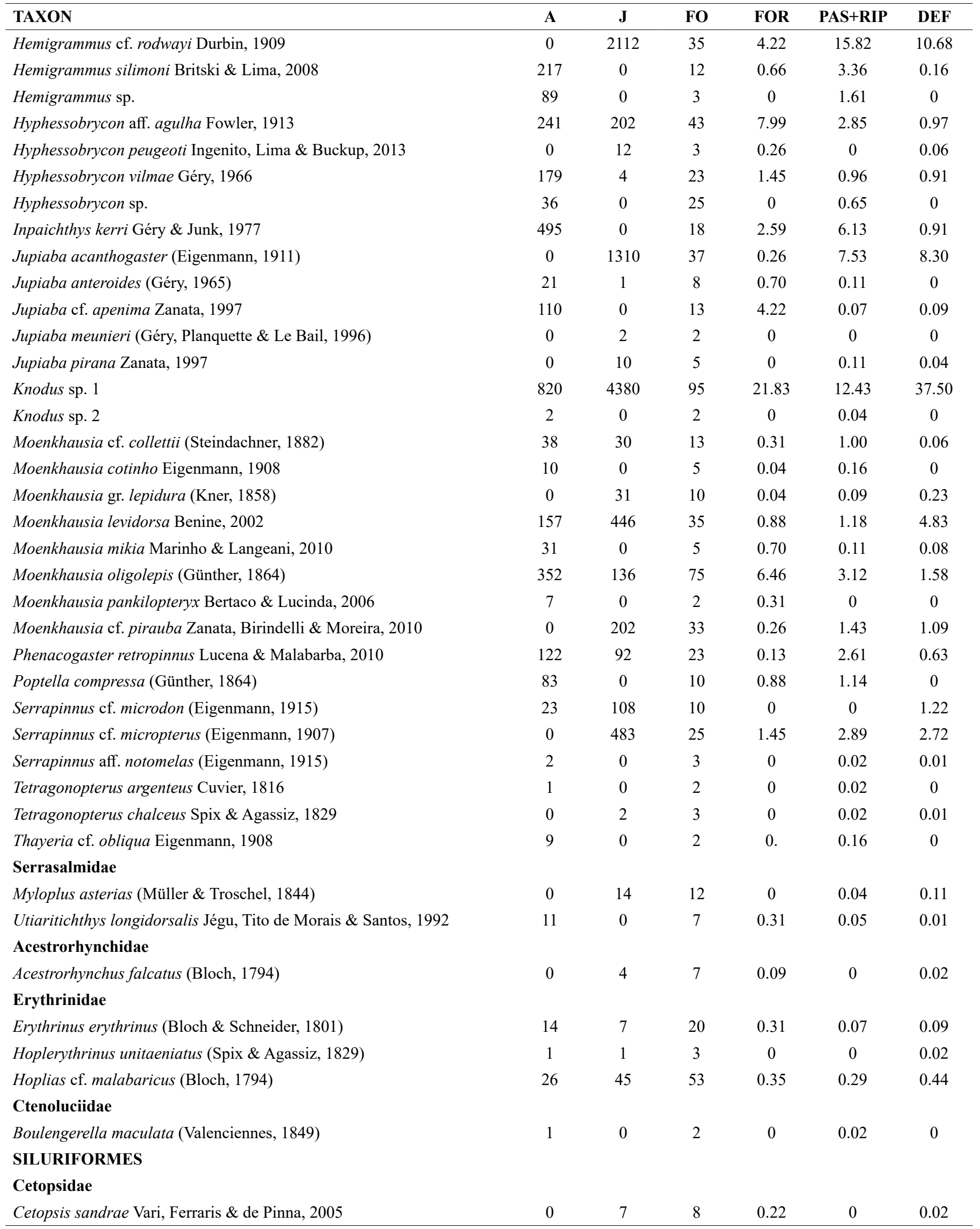


Continuation Table 2.

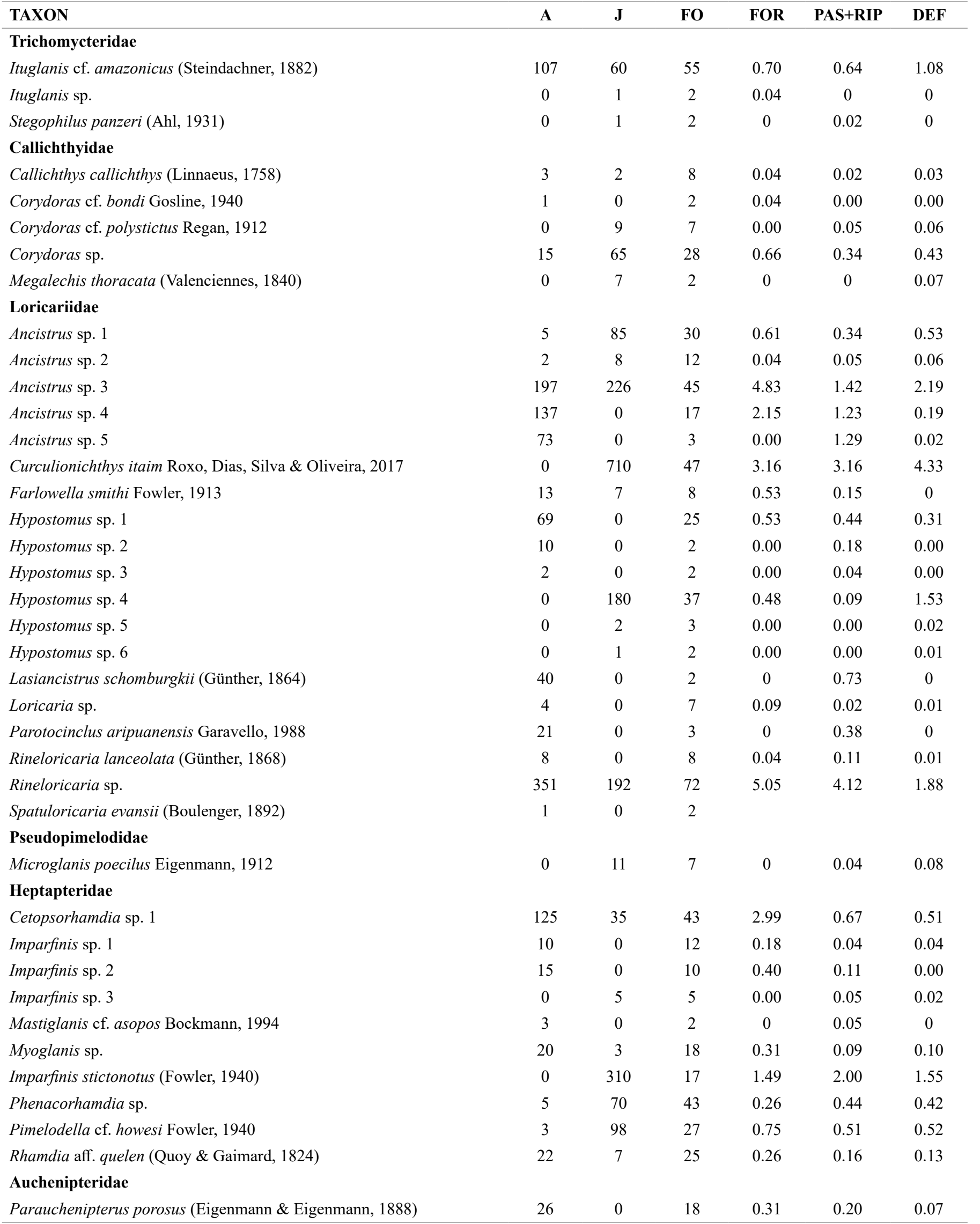


Continuation Table 2.

\begin{tabular}{|c|c|c|c|c|c|c|}
\hline TAXON & A & $\mathbf{J}$ & FO & FOR & PAS+RIP & DEF \\
\hline Tatia aulopygia (Kner, 1858) & 16 & 1 & 10 & 0.44 & 0.09 & 0.02 \\
\hline \multicolumn{7}{|l|}{ GYMNOTIFORMES } \\
\hline Gymnotus cf. carapo Linnaeus, 1758 & 16 & 17 & 32 & 0.35 & 0.11 & 0.18 \\
\hline \multicolumn{7}{|l|}{ Sternopygidae } \\
\hline \multicolumn{7}{|l|}{ Rhamphichthyidae } \\
\hline Gymnorhamphichthys rondoni (Miranda Ribeiro, 1920) & 0 & 1 & 2 & 0 & 0.02 & 0 \\
\hline \multicolumn{7}{|l|}{ Hypopomidae } \\
\hline Brachyhypopomus cf. sullivani Crampton, de Santana, Waddell \& & 1 & 11 & 13 & 0.09 & 0.05 & 0.07 \\
\hline
\end{tabular}

Lovejoy, 2017

\section{CYPRINODONTIFORMES}

\section{Poeciliidae}

Pamphorichthys cf. scalpridens (Garman, 1895)

\section{SYNBRANCHIFORMES}

\section{Synbranchidae}

Synbranchus cf. madeirae Rosen \& Rumney, 1972

0

3

2

0

0

0.03

\section{CICHLIFORMES}

\section{Cichlidae}

Aequidens gerciliae Kullander, 1995

Caquetaia spectabilis Steindachner, 1875

Cichla mirianae Kullander \& Ferreira, 2006

Crenicichla aff. acutirostris Günther, 1862

Crenicichla cf. hemera Kullander, 1990

Crenicichla aff. isbrueckeri Ploeg, 1991

Crenicichla aff. semicincta Steindachner, 1892

Geophagus cf. altifrons Heckel, 1840

Geophagus mirabilis Deprá, Kullander, Pavanelli \& Graça, 2014

Heros spurius Heckel, 1840

Oreochromis niloticus (Linnaeus, 1758)*

\section{TOTAL}

0

\section{8}

0.09

0.05

0.01

The predominance of small-sized characins is another common pattern observed in Amazonian streams (Barros et al. 2011, Brejão et al. 2013, Casatti et al. 2013, Montag et al. 2018). In general, these species are considered opportunistic regarding their feeding strategies, which show high trophic plasticity, being recognized as generalist feeders (Ferreira et al. 2012, Manna et al. 2012, Barros et al. 2017). Despite being commonly classified as opportunistic, these small characins occupy the habitat by using different strategies (see Ceneviva-Bastos $\&$ Casatti 2007, Brejão et al. 2013). There are species with fusiform bodies, forming numerous shoals and more specialized in the capture of items dragged by the current on the water surface, close to the stream bed (e.g., Knodus sp. 1) or in the marginal habitats (e.g. Hemigrammus cf. rodwayi, Inpaichthys kerri, Hyphessobrycon aff. agulha). Other species have relatively higher bodies, forming small groups with different food tactics that forage in different microhabitats (e.g., Jupiaba acanthogaster, Moenkhausia levidorsa, Moenkhausia oligolepis). Therefore, naturalistic studies are encouraged in the Amazonian streams to describe these behavioral differences and give subsidies for more complex ecological approaches.

Considering the overall assemblage, widespread species (those present in at least $50 \%$ of the streams) belong to more diversified groups in terms of their biology (see Van Der Sleen \& Albert 2018). Among them, there are the nektonic drift-feeding tetras (Knodus sp. 1, Moenkhausia oligolepis), the bottom-dwelling insectivores known as South American darters (Characidium aff. zebra) and catfishes (Ituglanis cf. amazonicus), the bentonic periphytivores armoured catfishes (Rineloricaria sp.), the nektobenthic sit-and-wait carnivores trahiras (Hoplias cf. malabaricus), the riverbank invertivores knifefishes (Eigenmannia macrops), and the nektobenthic omnivores cichlids (Aequidens gerciliae). 

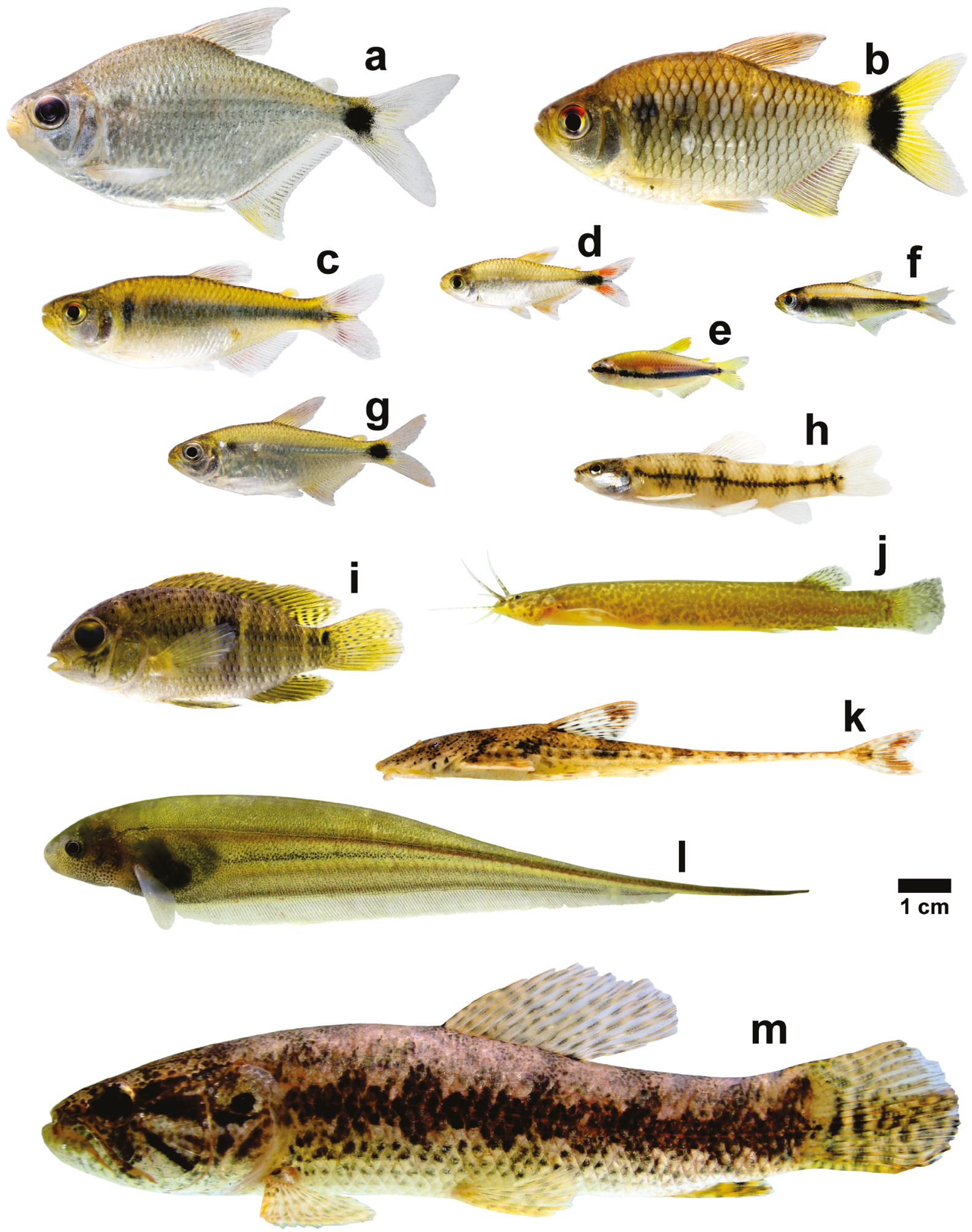

Figure 4. Species that contributed the most for total abundance and occurrence in the Aripuanã and Juruena river basins. a. Moenkhausia levidorsa; b. Moenkhausia oligolepis; c. Knodus sp. 1; d. Hemigrammus cf. rodwayi; e. Inpaichthys kerri; f. Hyphessobrycon aff. agulha; g. Jupiaba acanthogaster; h. Characidium aff. zebra; i. Aequidens gerciliae; j. Ituglanis cf. amazonicus; $k$. Rineloricaria sp.; 1. Eigenmannia macrops; m. Hoplias cf. malabaricus. Photos: Angelo Rodrigo Manzotti. 


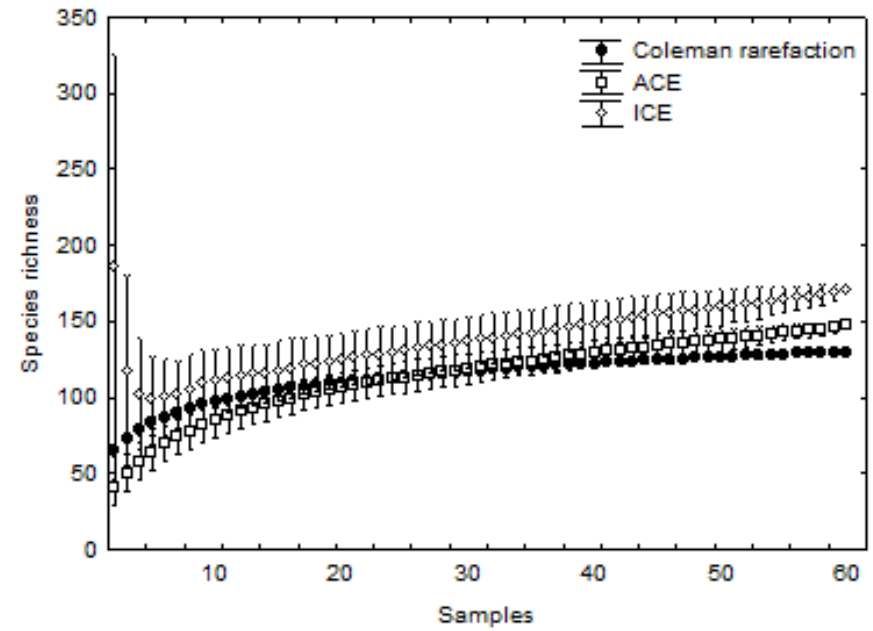

Figure 5. Observed richness (obtained by the Coleman rarefaction curve) and the curves of estimated number of species derived from ACE (Abundance Coverage Estimator) and ICE (Incidence Coverage Estimator) by 999 randomizations against cumulative samples.

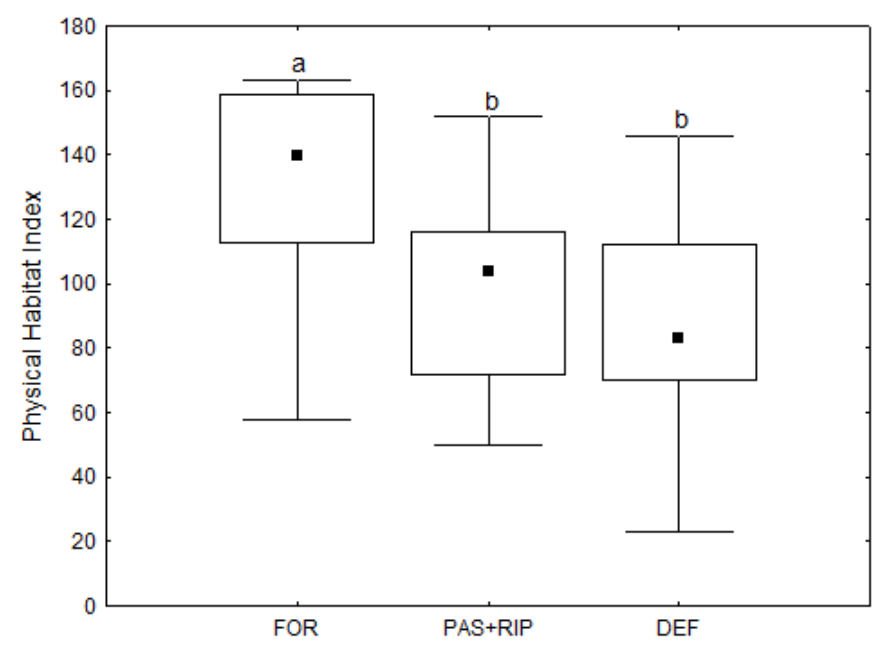

Figure 6. Physical Habitat Index for forested (FOR), pasture with riparian forests (PAS+RIP), and deforested streams (DEF). Squares represent median, boxes represent 25 th and 75 th percentiles, and lines represent the minimum and maximum values. Different letters indicate significant differences according to the Dunn's post-hoc test $(\mathrm{P}<0.05)$.

Rarity is another pattern observed from these assemblages since $15 \%$ of the species were singletons and $30 \%$ were uniques. This high occurrence of rare species mirrors another pattern for Amazonian streams, as indicated by several studies (e.g., Barros et al. 2011, Carvalho et al. 2011, Casatti et al. 2013, Ohara \& Loeb 2016, Montag et al. 2018). However, the set of rare species was not the same in Aripuanã River and in Juruena River. For instance, Geophagus mirabilis were rare in Aripuanã River, whereas Hemiodus bimaculatus and H. sterni were in Juruena River. According to Fernandes et al. (2013), differences in species composition between regions can be attributed to the success of each species in the colonization of distinct watersheds (local scale) or due to evolutionary events (regional scale). Considering that Aripuanã and river Juruena belong to different ecoregions, it is likely to presume that events at regional scale can be the primary driver for the differences observed in this study. Indeed, a recent study has revealed that the
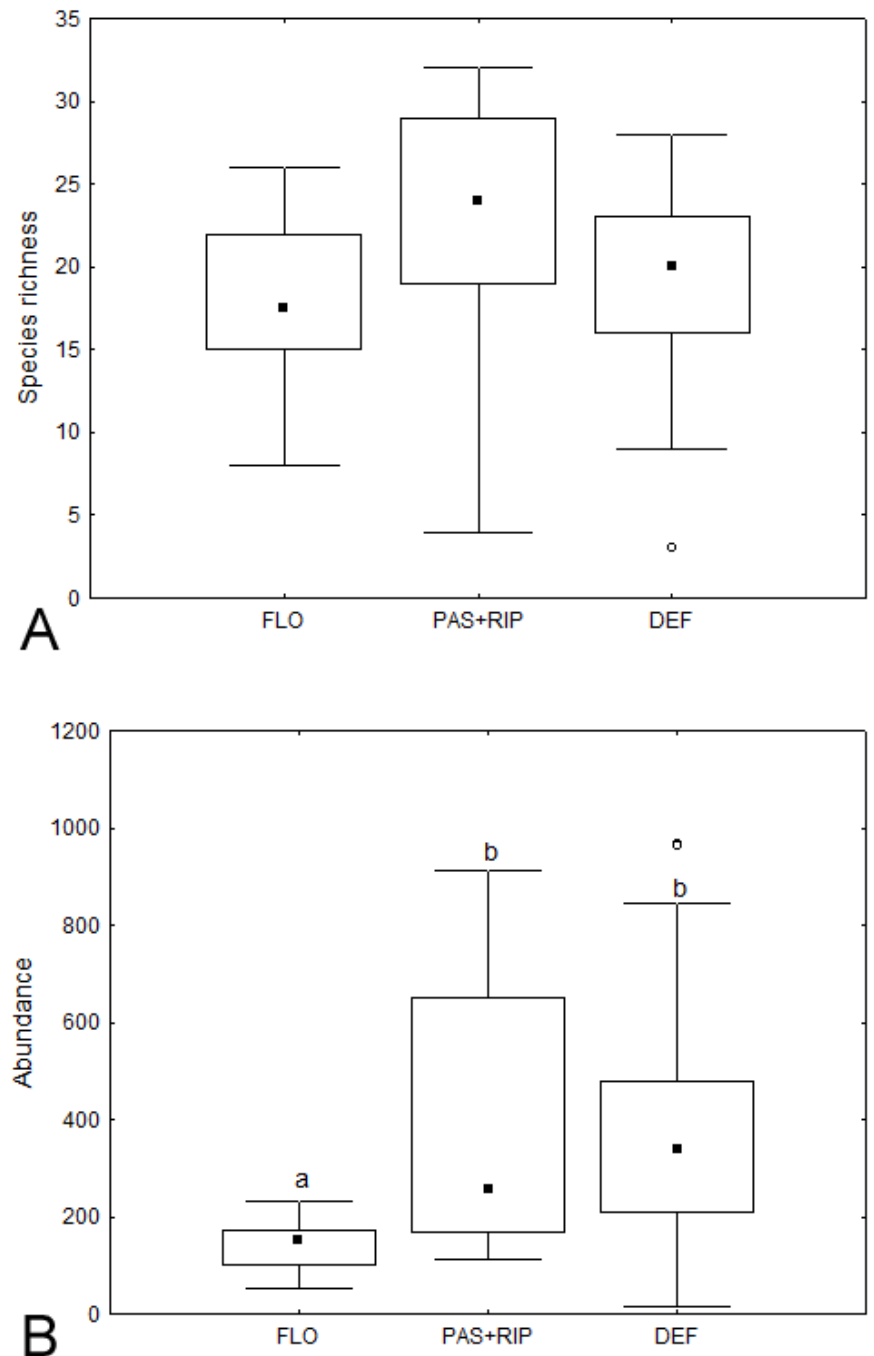

Figure 7. Species richness (A) and abundance (B) for forested (FOR), pasture with riparian forests (PAS+RIP), and deforested streams (DEF). Squares represent median, boxes represent 25 th and 75 th percentiles, lines represent the minimum and maximum values, and open circle represents outliers. Different letters indicate significant differences according to the Dunn's post-hoc test $(\mathrm{P}<0.05)$.

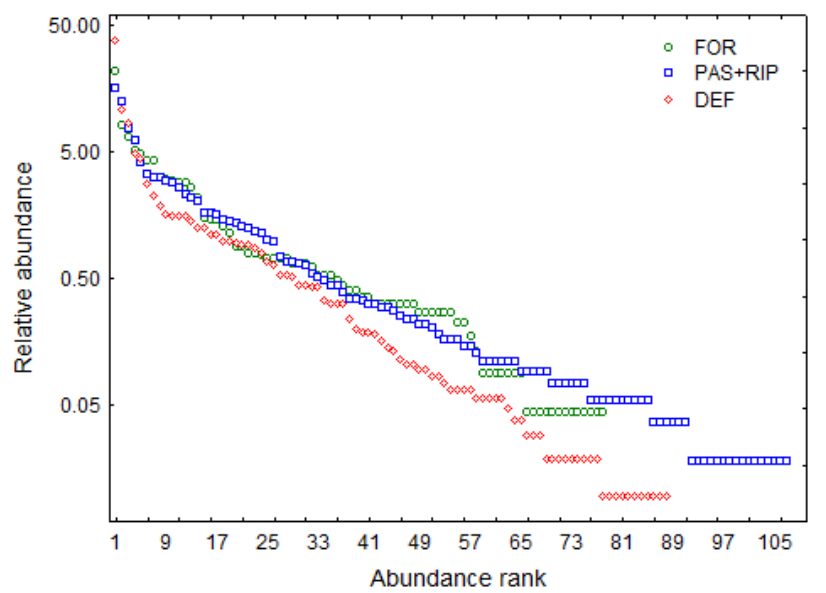

Figure 8. Rank-abundance distribution of fish fauna sampled in the forested (FOR), pasture with riparian forests (PAS+RIP), and deforested streams (DEF). $\mathrm{Y}$ axis shows species abundance; $\mathrm{X}$ axis ranks each species in order from most to least abundant. Each symbol represents one species. 
Dardanelos and Andorinhas waterfall complex is an important barrier for the fish fauna in the Aripuanã river basin (Silva et al. 2019).

Although streams from the forested group presented better physical habitat conditions than streams from the other groups, the species richness was similar among groups, which indicates that changes in the physical habitat have not already reached the threshold to affect fish richness. Based on our knowledge from a neighbor basin (Machado River, in Rondônia state), progression of the impacts over time may deteriorate physical habitat quality above this threshold leading to the replacement of sensitive species by more resistant ones, which affects the fish assemblage structure (Brejão et al. 2018). Unlike the species richness, the fish abundance was greater in the pasture with riparian forest and in the deforested streams than in the forested streams. Fish that contributed the most for the higher abundance in these two groups were the small characins that are, as previously discussed, opportunisticfeeders. In addition, their reproductive strategy can also be viewed as opportunistic, since they are able to grow fast, mature early, and spawn more than once annually (Winemiller 1989, Carvalho et al. 2007). These characteristics let them to successfully proliferate even in degraded conditions (Brejão et al. 2018). Indeed, Whittaker plots revealed that relative abundances are unevenly spread amongst the species from each stream group and, therefore, the abundance variation seems to be an important sentinel to signal early assemblages' responses to disturbance.

The high fish diversity in the Meridional Amazon showed a high proportion of rare, endemic and undescribed species. According to MMA (2019), these areas encompass high biological importance and should be a priority target for Brazilian biodiversity conservation actions. Unfortunately, uncontrolled land use changes are a reality in this region located on the boundaries of the Amazonian deforestation arc, which will continue to advance, notably if no effective measures would be taken to regulate deforestation.

\section{Acknowledgments}

We are grateful to Fundação de Amparo à Pesquisa do Estado de São Paulo for financial support (FAPESP, 2016/01535-3) and fellowship to GLB (2018/11954-9), to Project "Poço de Carbono Florestal PeugeotONF (São Nicolau Farm, Cotriguaçu, MT)" for logistical support. LC and FL receive grants from Conselho Nacional de Desenvolvimento Científico e Tecnológico (CNPq, 301877/2017-3, 305756/2018-4). HPS is a postdoctoral researcher and receives grant from Fundação de Amparo à Pesquisa do Estado de Mato Grosso: and Conselho Nacional de Desenvolvimento Científico e Tecnológico. (FAPEMAT, 594058/2017). BMSR was a Master student in the Animal Biology Program/UNESP, and received scholarship from Coordenação de Aperfeiçoamento de Pessoal de Nivel Superior (CAPES). MAPM was a postdoctoral researcher in UNESP (without financial support). FRC is supported by the Conselho Nacional de Desenvolvimento Científico e Tecnológico (process \# 420620/2018-4) and Fundação de Apoio ao Desenvolvimento do Ensino, Ciência e Tecnologia do Estado de Mato Grosso do Sul (process\# 59/300.093/2017, SIAFEM 27248).

\section{Author Contribution}

Lilian Casatti contributed to the concept and design of the study, data analysis, data interpretation, and manuscript preparation.
Gabriel Lourenço Brejão, Hugmar Pains da Silva, María Angélica Pérez-Mayorga, Angelo Rodrigo Manzotti, Jaquelini Oliveira Zeni, and Bruno Martins Santos Ramires contributed to field data collection, digitalization, analysis, interpretation, and critical revision, adding intellectual content.

Fernando Rogério Carvalho and Francisco Langeani contributed to fish identification, data interpretation and critical revision, adding intellectual content.

\section{Conflicts of interest}

The authors declare that they have no conflict of interest related to the publication of this manuscript.

\section{Ethics}

The study conforms to the legal Brazilian requirements regarding animal welfare, including those relating to fish euthanasia.

\section{Data availability}

Fish collection is available in the Species Link system (http:// splink.cria.org.br/).

\section{References}

ABELL, R., THIEME, M.L., REVENGA, C., BRYER, M., KOTTELAT, M., BOGUTSKAYA, N., COAD, B., MANDRAK, N., BALDERAS, S.C., BUSSING, W., STIASSNY, M.L.J., SKELTON, P., ALLEN, G.R., UNMACK, P., NASEKA, A., NG, R., SINDORF, N., ROBERTSON, J., ARMIJO, E., HIGGINS, J.V., HEIBEL, T.J., WIKRAMANAYAKE, E., OLSON, D., LOPEZ, H.L., REIS, R.E., LUNDBERG, J.G., PEREZ, M.H.S. \& PETRY, P. 2008. Freshwater ecoregions of the world: a new map of biogeographic units for freshwater biodiversity conservation. BioScience 58:403-414.

AGUIRRE-GUTIERREZ, J., BIESMEIJER, J.C., VAN LOON, E.E., REEMER, M., WALLIS DEVRIES, M.F. \& CARVALHEIRO, L.G. 2015. Susceptibility of pollinators to ongoing landscape changes depends on landscape history. Divers. Distrib. 21:1129-1140.

BARBOUR, M.T., GERRITSEN, J., SNYDER, B.D. \& STRIBLING, J.B. 1999. Rapid bioassessment protocols for use in streams and wadable rivers: periphyton, benthic macroinvertebrates and fish. Second edition. EPA 841-B-99-002. U. S. Environmental Protection Agency; Office of Water, Washington, D.C.

BARROS, D.F., ZUANON, J., MENDONÇA, F.P., ESPÍRITO-SANTO, H.M.V., GALUCH, A.V. \& ALBERNAZ, A.L.M. 2011. The fish fauna of streams in the Madeira-Purus interfluvial region, Brazilian Amazon. Check List 7(1):768-773.

BARROS, G., ZUANON, J. \& DEUS, C. 2017. Effects of species co-occurrence on the trophic niche breadth of characids in Amazon forest streams. J. Fish Biol. 90(1):326-340.

BREJÃO, G.L., GERHARD, P. \& ZUANON, J. 2013. Functional trophic composition of the ichthyofauna of forest streams in eastern Brazilian Amazon. Neotrop. Ichthyol. 11(2):361-373.

BREJÃO, G.L., HOEINGHAUS, D.J., PÉREZ-MAYORGA, M.A., FERRAZ, S.F.B. \& CASATTI, L. 2018. Threshold responses of Amazonian stream fishes to timing and extent of deforestation. Conserv. Biol. 32(4):860-871.

BUCKUP, P.A., BRITTO, M.R., GOMES, J.R., BIRINDELLI, J.L.O., LIMA, F.C.T., MALDONADO-OCAMPO, J.A., ZAWADZKI, C.H., CARVALHO, F.R., JEREP, F.C., CHAMON, C.C., FRIES, L.C.C., VILLA-VERDE, L., CAMARGO, M., SOUZA-LIMA, R., BARTOLETTE, R. \& WINGERT, J.M. 2011. Inventário da ictiofauna da Ecorregião Aquática Xingu-Tapajós. In Ecorregião Aquática Xingu-Tapajós. CETEM/MCT, Rio de Janeiro, p.163-174. 
CARVALHO, F.R., CASATTI, L., BREJÃO, G.L., MANZOTTI, A.R., SILVA, H.P. \& LANGEANI, F. 2018. Dois táxons novos de piabas, Astyanax Girard \& Baird e Hyphessobrycon Durbin (Characiformes: Characidae), da Amazônia Meridional. XXIII Encontro Brasileiro de Ictiologia. Sociedade Brasileira de Ictiologia, Belém, p.433. http://www.ebi2019.com. br/LIVRO RESUMOS EBI2019 VERSAO FINALISSIMA.pdf (last accessed in 14/06/2019).

CARVALHO, L.N., LIMA FILHO, J.A., RODRIGUES, R.R. \& ZUANON, J. 2011. Peixes de igarapés da Fazenda São Nicolau, bacia do rio Juruena. In Descobrindo a Amazônia Meridional: biodiversidade da Fazenda São Nicolau (D.J. Rodrigues, T.J. Izzo \& L.D. Battirola, orgs). Ed. Pau e Prosa Comunicação Ltda, Cuiabá, p.105-124.

CARVALHO, L.N., ZUANON, J. \& SAZIMA, I. 2007. Natural history of amazon fishes. In International Commision on Tropical Biology and Natural Resources (K. Del Claro et al., eds). Encyclopedia of Life Support Systems (EOLSS), Developed under the Auspices of the UNESCO, Eolss Publishers, Oxford ,UK, 32p.

CASATTI, L., LANGEANI, F. SILVA, A.M. \& CASTRO, R.M.C. 2006. Stream fish, water and habitat quality in a pasture dominated basin, southeastern Braz. Braz. J. Biol. 66(2B):681-696.

CASATTI, L., PÉREZ-MAYORGA, M.A., CARVALHO, F.R., BREJÃO, G.L. \& COSTA, I.D. 2013. The stream fish fauna from the rio Machado basin, Rondônia State, Brazil. Check List 9:1496-1504.

CENEVIVA-BASTOS, M. \& CASATTI, L. 2007. Oportunismo alimentar de Knodus moenkhausii (Teleostei, Characidae): uma espécie abundante em riachos do noroeste do Estado de São Paulo, Brasil. Iheringia, Zool. 97(1):7-15

COLWELL, R.K., MAO, C.X. \& CHANG, J. 2004. Interpolating, extrapolating, and comparing incidence-based species accumulation curves. Ecology $85: 2717-2727$

COLWELL, R.K. 2013. EstimateS 9.1.0. Statistical estimation of species richness and shared species from samples. Software. University of Connecticut.

FERNANDES, I.M., LOURENÇO, L.S., OTA, R.P., MOREIRA, M.M.M. \& ZAWADZKI, C.H. 2013. Effects of local and regional factors on the fish assemblage structure in meridional Amazonian streams. Environ. Biol. Fish. 96:837-848.

FERRAZ, S.F.B., VETTORAZZI, C.A. \& THEOBALD, D.M. 2009. Using indicators of deforestation and land-use dynamics to support conservation strategies: a case study of central Rondônia, Brazil. Forest Ecol. Manag. 257(7):1586-1595.

FERREIRA,A., PAULA, F.R., FERRAZ, S.F.B., GERHARD, P., KASHIWAQUI, E.A., CYRINO, J.E.P. \& MARTINELLI, L.A. 2012. Riparian coverage affects diets of characids in neotropical streams. Ecol. Freshw. Fish. 21(1):12-22.

FERREIRA, M.C., BEGOT, T.O., PRUDENTE, B.S., JUEN, L. \& MONTAG, L.F.A. 2018. Effects of oil palm plantations on habitat structure and fish assemblages in Amazon streams. Environ. Biol. Fish. 101:547-562.

HAMMER, Ø., HARPER, D.A.T. \& RYAN, P.D. 2001. PAST: Paleontological Statistics Software Package for Education and Data Analysis. Palaeontol. Electron. 4(1):1-9.

HARDING, J.S., BENEFIELD, E F., BOLSTAD, P.V., HELFMAN, G.S. \& JONES III, E.B.D. 1998. Stream biodiversity: The ghost of land use past. P Natl Acad Sci-Biol. 95:14843-14847.

JONSSON, B., JONSSON, N. \& UGEDAL, O. 2011. Production of juvenile salmonids in small Norwegian streams is affected by agricultural land use. Freshwater Biol. 56:2529-2542.

KAZYAK, P.F. 2001. Maryland biological stream survey: sampling manual. Maryland Department of Natural Resources, Monitoring and Non-tidal Assessment Division, Annapolis.

LEE, S.M. \& CHAO, A. 1994. Estimating population size via sample coverage for closed capture-recapture models. Biometrics 50(1):88-97.

LORION, C.M. \& KENNEDY, B.P. 2009. Riparian forest buffers mitigate the effects of deforestation on fish assemblages in tropical headwater streams. Ecol. Appl. 19(2):468-479.
LOWE-McCONNELL, R.H. 1999. Estudos ecológicos de comunidades de peixes tropicais. Editora da Universidade de São Paulo, São Paulo.

LUCENA, C.A.S., CALEGARI, B.B., PEREIRA, E.H.L. \& DALLEGRAVE, E. 2013. O uso do óleo de cravo na eutanásia de peixes. Bol. Soc. Bras. Ictiol. 105:20-24.

LUKE, S.H., SLADE, E.M., GRAY, C.L., ANNAMMALA K.V., DREWER, J., WILLIAMSON, J., AGAMA, A.L., ATIONG, M., MITCHELL, S.L., VAIRAPPAN, C.S. \& STRUEBIG, M.J. 2019. Riparian buffers in tropical agriculture: Scientific support, effectiveness and directions for policy. J. Appl. Ecol. 56(1):85-92.

MALONEY, K. \& WELLER, D.E. 2011. Anthropogenic disturbance and streams: land use and land-use change affect stream ecosystems via multiple pathways. Freshwater Biol. 56:611-626.

MMA(Ministério do Meio Ambiente). 2019. Áreas prioritárias para Conservação da Biodiversidade Brasileira. http://areasprioritarias.mma.gov.br/2atualizacao-das-areas-prioritarias? fbclid $=\mathrm{IwAR} 2 \mathrm{NYSgUudkV} 28 \mathrm{gCeeq}$ Az0gUM-RsizUbxxSXJR21e_nvwWvLcqDlldbBGHA (last accessed in 14/06/2019).

MANNA, L.R.; REZENDE, C.F. \& MAZZONI, R. 2012. Plasticity in the diet of Astyanax taeniatus in a coastal stream from south-east Brazil. Braz. J. Biol. 72(4):919-928.

MAPBIOMAS. 2019. Projeto MapBiomas - Coleção v.3.0 da Série Anual de Mapas de Cobertura e Uso de Solo do Brasil. http://mapbiomas.org/ (last accessed in 20/01/2019).

MATTHEWS, T.J. \& WHITTAKER, R.J. 2015. On the species abundance distribution in applied ecology and biodiversity management. J. Appl. Ecol. 52:443-454.

MONTAG, L.F.A., WINEMILLER, K.O., KEPPELER, F.W., LEÃO, H., BENONE, N.L., TORRES, N.R., PRUDENTE, B.S., BEGOT, T.O., BOWER, L.M., SAENZ, D.E., LOPEZ-DELGADO, E.O., QUINTANA, Y., HOEINGHAUS, D.J. \& JUEN, L. 2018. Land cover, riparian zones and instream habitat influence stream fish assemblages in the eastern Amazon. Ecol. Freshw. Fish 2018:1-13.

NOGUEIRA, A., LANGEANI, F. \& NETTO-FERREIRA, A. 2019. Hemiodus bimaculatus, a new species of Hemiodontidae from the Rio Tapajós drainage, Brazil (Ostariophysi: Characiformes). J. Fish Biol. 94(5):798-803.

OHARA, W.M. \& LOEB, M.V. 2016. Ichthyofauna of the upper Juruena river on Chapada dos Parecis, Mato Grosso, Brazil. Biota Neotrop. 16(4): e20160224. http://dx.doi.org/10.1590/1676-0611-BN-2016-0224 (last accessed in 15/06/2019).

OHARA, W.M., LIMA, F.C.T., SALVADOR, G.N. \& ANDRADE, M.C. 2017. Peixes do rio Teles Pires: diversidade e guia de identificação. Gráfica Amazonas e Editora Ltda, Goiás.

ÖSTLUND, L., HÖRNBERG, G., DeLUCA, T.H., LIEDGREN, L., WIKSTRÖM, P., ZACKRISSON, O. \& JOSEFSSON, T. 2015. Intensive land use in the Swedish mountains between AD 800 and 1200 led to deforestation and ecosystem transformation with long-lasting effects. Ambio 44:508-520.

PICOLI, M.C.A., CAMARA, G., SANCHES, I., SIMÕES, R., CARVALHO, A., MACIEL, A., COUTINHO, A., ESQUERDO, J., ANTUNES, J., BEGOTTI, R.A., ARVOR, D. \& ALMEIDA, C. 2018. Big earth observation time series analysis for monitoring Brazilian agriculture. ISPRS J. Photogramm. Remote Sens. 145:328-339.

PUSEY, B.J. \& ARTHINGTON, A.H. 2003. Importance of the riparian zone to the conservation and management of freshwater fish: a review. Mar. Freshwater Res. 54:1-16.

QUEIROZ, L.J., TORRENTE-VILARA, G., OHARA, W.M., PIRES, T.H.S., ZUANON, J. \& DORIA, C.R.C. 2013. Peixes do Rio Madeira. Volumes I, II, III, Dialeto, São Paulo.

QUINN, J. 2005. Effects of rural land use (especially forestry) and riparian management on stream habitat. New Zeal. J. For. 49:16-19.

REIS, R.E., KULLANDER, S.O. \& FERRARIS, C.J.Jr. (eds). 2003. Check list of the freshwater fishes of South and Central America. Edipucrs, Porto Alegre. 
ROTH, N.E., ALLAN, J.D. \& ERICKSON D.L. 1996. Landscape influences on stream biotic integrity assessed at multiple spatial scales. Land. Ecol. 11:141-156

RUARO, R., MORMUL, R.P., GUBIANI, E.A., PIANA, P.A., CUNICO, A.M. \& GRACA, W.J. 2018. Non-native fish species are related to the loss of ecological integrity in Neotropical streams: a multimetric approach. Hydrobiol. 817:413-430.

SILVA, H.P., ZAWADZKI, C.H., LOURENÇO, L.S. \& FERNANDES, I.M. 2019. Stream fish in the Aripuanã river upstream and downstream of the Dardanelos-Andorinhas waterfall complex, state of Mato Grosso, Brazil. Oecologia Australis, 23:606-619.

SOARES, M.G.M. 1979. Aspectos ecológicos (alimentação e reprodução) dos peixes do igarapé do Porto, Aripuanã, MT. Acta Amaz. 9(2):325-352.

STRAHLER, A.N. 1957. Quantitative analysis of watershed geomorphology. Trans. Am. Geophys. Union 38:913-920.
STAUFFER, J.C., GOLDSTEIN, R.M. \& NEWMAN, R.M. 2000. Relationship of wooded riparian zones and runoff potential to fish community composition in agricultural streams. Can. J. Fish. Aquat. Sci. 57:307-316.

TEELS, B.M., REWA, A.A. \& MYERS, J. 2006. Aquatic condition response to riparian buffer establishment. Wildlife Soc. B. 34:927-935.

VALDIONES, A., SILGUEIRO, V., BERNASCONI, P., THUALT, A. \& CARDOSO, B. 2018. Amazon forest deforestation in Mato Grosso (Prodes 2018). https://www.icv.org.br/wp-content/uploads/2018/12/Prodes-2018EN-Amazon-Deforestation-MT.pdf (last accessed in 15/01/2019).

VAN DER SLEEN, P. \& ALBERT, J.S. (orgs). 2018. Field guide to the fishes of Amazon, Orinoco \& Guianas. Princeton University Press, New Jersey.

WINEMILLER, K.O. 1989. Patterns of variation in life history among South American fishes in seasonal environments. Oecologia 81:225-241.

WORLD WILDLIFE FUND \& THE NATURE CONSERVANCY. 2015. Freshwater ecoregions of the world. Data downloaded from www.feow. org (last accessed in 15/01/2019). 